\title{
A new genus of syringophilid mites (Acari: Cheyletoidea: Syringophilidae) from cuculiform birds (Aves: Cuculiformes)
}

\author{
Maciej Skoracki \\ Department of Animal Morphology, A. Mickiewicz University, Umultowska 89, 61-614 Poznan, Poland \\ Key words: Syringophilidae, Cuculisyringophilus crotophaginus, quill mites, Cuculiformes, Guira guira, \\ Crotophaga sulcirostris, ectoparasites, taxonomy
}

\begin{abstract}
Cuculisyringophilus crotophaginus gen. n. et sp. n. is described from the guira cuckoo Guira guira (Gmelin) from Paraguay and also was collected from the groove-billed ani Crotophaga sulcirostris Swainson from Colombia and Mexico. This new genus is closely related to Neoaulobia Fain, Bochkov et Mironov, 2000 but is distinguished by the following characters: propodosomal setae sce are situated distinctly anterior to level of setae d1, leg setae $v s$ 'II are absent, apodemes I are divergent.
\end{abstract}

Members of the family Syringophilidae (Acari: Cheyletoidea) are obligatory ectoparasites of birds, inhabiting quills of the flight and covert feathers. In these unique habitats they feed on the soft tissue by piercing the quill wall with their styletiform chelicerae. Reproduction and development also takes place inside the quills (Kethley 1970, Casto 1974).

Our knowledge of syringophilid fauna is still fragmentary. To date, this family includes about 140 named species belonging to 35 genera and grouped into two subfamilies: Syringophilinae Lavoipierre, 1953 (33 genera) and Picobiinae Johnston et Kethley, 1973 (2 genera) (Bochkov et al. 2004, Skoracki and Sikora 2004, 2005, Skoracki 2005). Likewise, the quill mites parasitizing cuculiform birds are poorly investigated. Only two species were reported from these birds: Calamincola lobatus (Casto, 1978) from the groove-billed ani Crotophaga sulcirostris Swainson from the USA, and Niglarobia chirovi Bochkov et Mironov, 1998 from the common cuckoo Cuculus canorus Linnaeus from Russia.

In this paper, a new genus Cuculisyringophilus is proposed to accommodate a new syringophilid species collected from the guira cuckoo Guira guira (Gmelin) from Paraguay and the groove-billed ani Crotophaga sulcirostris Swainson from Colombia and Mexico.

\section{MATERIALS AND METHODS}

The syringophilids were acquired from bird specimens (dry skins) housed in the Zoologische Staatssammlung, München (Germany). Initially, mites were placed in lactic acid (10\%) for three days. Later, they were mounted on slides in Faure medium and examined using an Olympus $\mathrm{BH} 2$ microscope with differential interference contrast (Nomarski) optics.

The nomenclature of idiosomal setae is based on that of Fain (1979) in the version adapted for the family Syringophilidae (Bochkov and Mironov 1998) and the chaetotaxy for the legs is that of Grandjean (1944). Bird taxonomy follows Howard and Moore (1991). All measurements are given in micrometres $(\mu \mathrm{m})$. Abbreviations for institutions where the materials are deposited: AMU - Department of Animal Morphology, A. Mickiewicz University, Poznań, Poland; ZIN Zoological Institute of the Russian Academy of Sciences, St. Petersburg, Russia; ZSM - Zoologische Staatssammlung München, Germany.

\section{RESULTS}

Family: S y r i n g o p h i 1 i d a e Lavoipierre, 1953

Subfamily: Syringophilinae Lavoipierre, 1953

Genus: Cuculisyringophilus gen. n.

Diagnosis. Female. Small-sized mites, total length approximately 500-600. Gnathosoma. Hypostomal apex smooth, without protuberances, hypostomal lips with 2 pairs of small protuberances. Chelicerae edentate. Peritremes M-shaped. Lateral hypostomal teeth absent. Stylophore slightly constricted posteriorly. Idiosoma. All idiosomal setae smooth. Propodosomal shield well developed, not divided, rectangular. Propodonotal region with 6 pairs of setae, bases of setae $d 1$ situated posterior to level of bases of setae sce. Hysterosomal shield absent, pygidial shield present. Setae $d 4$ and $d 5$ short, more than 10 times shorter than whip-like setae 15. Genital and anal series with 2 pairs of setae each, paragenital series with 3 pairs of setae. Legs. All legs subequal in size. Apodemes I divergent, not fused to apodemes II. Setae dTIII, dTIV and vs'II absent. Antaxial and paraxial members of claw pair small and similar in shape, without basal angle.

Male. Characters as in female except for propodosomal shield weakly sclerotized, hysterosomal shield present, fused with pygidial shield. Setae 15 more than 2 times longer than $d 5$.

Type and only species: Cuculisyringophilus crotophaginus sp. n. Host order: Cuculiformes.

E t y m o lo g y: This generic name is derived from the name of the bird order Cuculiformes, hosting mites of this genus. 


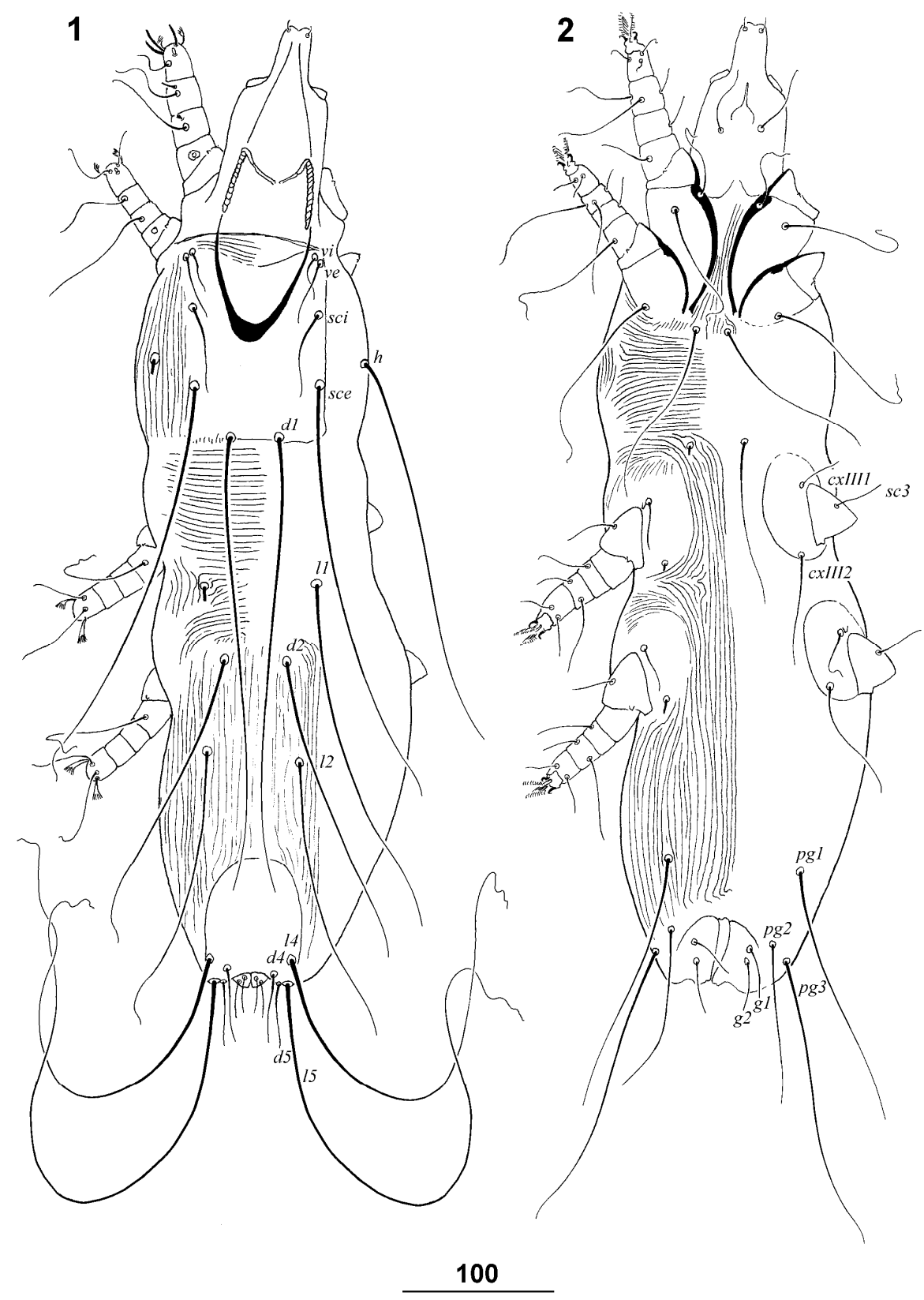

Figs. 1, 2. Cuculisyringophilus crotophaginus sp. n., female. Fig. 1. Dorsal view. Fig. 2. Ventral view. Scale bar in $\mu \mathrm{m}$.

Remarks. Cuculisyringophilus is closely related to Neoaulobia Fain, Bochkov et Mironov, 2000 associated with psittaciform birds (Fain et al. 2000). In both genera the chelicerae are edentate, the setal pattern of the propodonotal region is with 6 pairs of setae, the genital and anal series are with 2 pairs of setae each, 3 pairs of the paragenital setae are present, leg setae dTIII and dTIV are absent. The new genus is distinguished by the following characters: in females of Cuculisyringophilus, propodonotal setae sce are situated distinctly anterior to the level of setae $d 1$; in both sexes, leg setae vs'II are absent, apodemes I are divergent. In females of Neoau- lobia, propodosomal setae $d 1$ and sce are situated at the same transverse level; in both sexes, leg setae vs'II are present, apodemes I are parallel.

Cuculisyringophilus crotophaginus sp. n. Figs. 1-9

Description. Female. Total body length of holotype 650 (605-660 in 10 paratypes). Gnathosoma. Hypostomal apex rounded, with 2 pairs of short and fingerlike hypostomal lips (Fig. 5). Cheliceral digit 180 (170$180)$, long. Stylophore slightly constricted or rounded posteriorly, 215 (210-220) long. Each transverse branch 

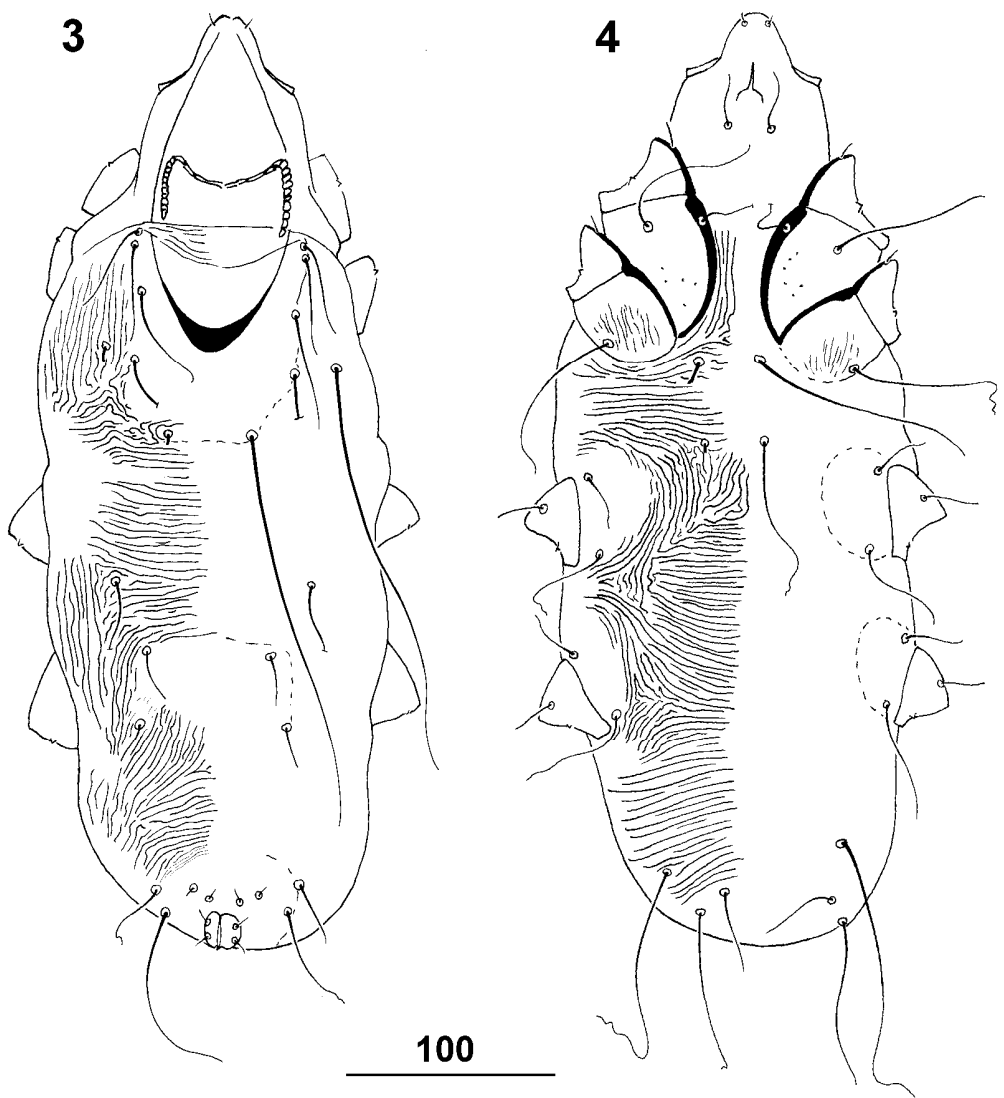

Figs. 3, 4. Cuculisyringophilus crotophaginus sp. n., male. Fig. 3. Dorsal view. Fig. 4. Ventral view. Scale bar in $\mu \mathrm{m}$.

of peritremes with 3-4 chambers, each longitudinal branch with 11-12 chambers (Fig. 6). Idiosoma. Propodosomal shield well sclerotized, rectangular, bearing bases of setae vi, ve, sci, sce and $d 1$. Length ratio of setae vi:ve:sci 1:1.2:2-3. Setae sce, $h$, and $d 1$ subequal in length. Hysterosomal shield absent. Pygidial shield present, well sclerotized, bearing bases of setae $d 4, d 5$, 14 and 15 . Bases of setae $d 2$ situated equidistant to bases of setae $l 1$ and 12 . Setae $d 4$ and $d 5$ subequal in length. Genital setae ( $g 1$ and $g 2$ ) twice longer than anal setae (a1 and a2). Paragenital setae pg1 and pg3 about 1.5 times longer than pg2. Cuticular striations as in Figs. 1 and 2. Legs. All coxal fields well sclerotized. Fan-like setae $p$ ' and $p$ " of legs III and IV with 7 tines. Setae tc"III-IV 1.5 times longer than tc'III-IV. Coxal setae cxIII2 about 1.5 times longer than cxIII1. Length of setae. vi (25-30); ve 35 (35-40); sci (50-70); h 250 (250-290); sce (270-290); d1 290 (275-300); l1 270 (250-270); d2 235 (215-245); 12 (175-215); d4 50 (45$50)$; d5 50 (40-50); 14 (100); 15 (305-340); $a 1$ and $a 2$ 25 (20-25); g1 50 (40-50); g2 45 (40-50); pg1 170 (170-175); pg2 115 (105-125); pg3 200 (170-225); sc1 and sc2 15 (15); sc3 50 (30-50); sc4 35 (30-40); cxIII1 40 (35-40); cXIII2 75 (75-80); tc'III-IV 50 (45-50); tc"III-IV 75 (65-75).

Male. Total body length $460-475$ in 3 paratypes. Gnathosoma. Stylophore rounded posteriorly, 180 long.
Each transverse branch of peritremes with 3-4 chambers, each longitudinal branch with 11-12 chambers (Fig. 8). Idiosoma. Propodosomal shield weakly sclerotized, lateral and posterior margins indistinct. Setae vi and ve subequal in length. Hysterosomal shield weakly sclerotized, with indistinct margins, bearing bases of setae d2. Pygidial shield present, variable in shape, bearing bases of setae $d 5$ and 15 . Bases of setae $d 2$ situated equidistant to bases of setae $l 1$ and $l 2$. Setae $d 4$ and $d 5$ subequal in length. Setae 15 variable in length, subequal or 2 times longer than setae $d 5$. Paragenital setae pg2 about 3 times shorter than pg1 and 1.5 times shorter than pg3. Cuticular striations as in Figs. 3 and 4. Legs. All coxae weakly sclerotized. Fan-like setae $p$ ' and $p$ " of legs III and IV with 7 tines. Setae tc"III-IV 1.5 times longer than $t c$ 'III-IV. Coxal setae cxIII2 about 1.5-2 times longer than cxIII1. Length of setae. vi 40-45; ve 40-45; sci 55-65; $h$ 215-220; d1 195-230; 11 more than 65 ; d2 25-30; 12 25-30; d5 40-45; 15 30-90; pg1 125145; pg2 40-50; pg3 70-85; sc3 and sc4 25-35; cxIII1 20-30; cxIII2 55-65.

T y p e h o s t : Guira guira (Gmelin, 1788) (Cuculidae: Crotophaginae).

$\mathrm{S}$ i t e : Quills of secondary feathers.

T y p e 1 o c a 1 i t y : Paraguay, Cambyrila; 18 June 1937; coll. A. Neunteufel. 


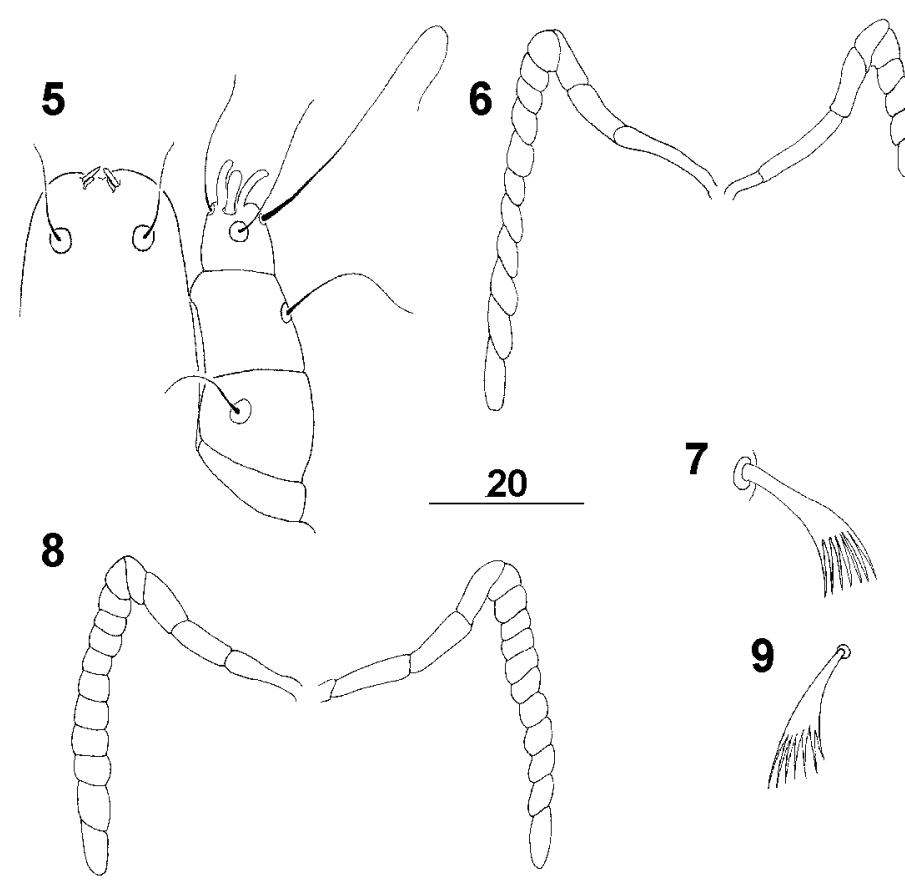

Figs. 5-9. Cuculisyringophilus crotophaginus sp. n., female (Figs. 5-7) and male (Figs. 8, 9). Fig. 5. Hypostomal apex. Fig. 6. Peritremes. Fig. 7. Fan-like seta p' of leg III. Fig. 8. Peritremes. Fig. 9. Fan-like seta p' of leg III. Scale bar in $\mu \mathrm{m}$.

T y p e s p e c i m e n s: Female holotype, 35 female and 3 male paratypes (No. Syr. 151).

S p e c i m e n s d e p o s i t e d: Holotype and most of the paratypes are deposited at AMU; 5 female and 1 male paratypes at ZIN and 5 female paratypes at ZSM.

E t y m o 1 o g y: The name crotophaginus refers to the subfamily name of the host - Crotophaginae.

A d d i t i o n a $1 \mathrm{~m}$ a t e r i a $1: 32$ females, 5 males, 9 nymphs (No. Syr.155) from quills of secondary feather of the groove-billed ani Crotophaga sulcirostris Swainson,
1827 (Cuculidae: Crotophaginae); Colombia, Bogota, no other data. This material is deposited at AMU.

Eight females (No. Syr.155a) from the same host and site; Mexico, Jalisco; 10 October 1912; coll. Gluckert. This material is deposited at AMU except for 2 females at ZSM and 2 females and 1 male at ZIN.

Acknowledgements. I would like to express my appreciation to Profs. Gerhard Haszprunar, Josef H. Reichholf and Drs. Richard Kraft and Stefan Friedrich (Zoologische Staatssammlung, München, Germany) for making available samples of bird skins for the present study and for help during work.

\section{REFERENCES}

Bochov A.V., MironOV S.V. 1998: Quill mites of the family Syringophilidae Lavoipierre, 1953 (Acariformes: Prostigmata) parasitic on birds (Aves) of the fauna of the former USSR. Acarina 6: 3-16.

BOCHOV A.V., FAIN A., SKORACKI M. 2004: New quill mites of the family Syringophilidae (Acari: Cheyletoidea). Syst. Parasitol. 57: 135-150.

CASTO S.D. 1974: Quill wall thickness and feeding of Syrinogophiloidus minor (Berlese) (Acarina: Syringophilidae). Ann. Entomol. Soc. Am. 67: 824.

FAIN A. 1979: Idiosomal and leg chaetotaxy in the Cheyletidae. Int. J. Acarol. 5: 305-310.

FAIN A., BochKOv A.V., MirONOv S.V. 2000: New genera and species of quill mites of the family Syringophilidae (Acari: Prostigmata). Bull. Inst. R. Sci. Nat. Belg. 70: 33-70.

GRANDJEAN F. 1944: Observations sur les acariens de la famille Stigmaeidae. Arch. Sci. Phys. Nat. 26: 103-131.
Howard R., MOORE A.A. 1991: A Complete Checklist of the Birds of the World. Oxford University Press, London, $701 \mathrm{pp}$.

KetHLEY J.B. 1970: A revision of the family Syringophilidae (Prostigmata: Acarina). Contrib. Am. Entomol. Inst. 5: 1-76.

SKORACKI M. 2005: A new genus of ectoparasitic mites of the family Syringophilidae (Acari: Cheyletoidea) from the treeswifts (Apodiformes: Hemiprocnidae). Acta Parasitol. 50: 336-343.

SKORACKI M., SIKORA B. 2004: A new genus and four new species of quill mites (Acari: Prostigmata: Syringophilidae) from phasianid birds (Galliformes: Phasianidae). Parasite 11: 379386.

SKORACKI M., SIKORA B. 2005: Neosyringophilopsis, a new genus of the subfamily Syringophilinae (Acari: Syringophilidae). Zootaxa 1052: 21-28.

Accepted 9 January 2008 